\title{
PENINGKATAN PENGETAHUAN PETANI TERHADAP INFORMASI PEMBIAYAAN DI KABUPATEN GARUT
}

\author{
${ }^{1}$ Eliana Wulandari, ${ }^{2}$ Ernah, ${ }^{3}$ Hepi Hapsari ${ }^{3}$ \\ ${ }^{1,2,3}$ Fakultas Pertanian, Universitas Padjadjaran, Jawa Barat, Indonesia \\ email: ${ }^{1}$ eliana.wulandari@unpad.ac.id; ${ }^{2}$ ernah@unpad.ac.id; ${ }^{3}$ hepi.hapsari@unpad.ac.id
}

\begin{abstract}
Information plays important role in agricultural finance. The availability of clear and precise information can determine the success of farmers in obtaining financing for farming. This community service was conducted to improve the knowledge and skills of farmers in accessing information about financing from various sources of finance. This program applied the methods of socializing, training, and mentoring activities. The material provided in this training activity was to provide information on various sources of finance around farmers, and various information related to the conditions for obtaining finance from various sources of finance, as well as activities that need to be done in order to get access to financial information
\end{abstract}

Keywords: community service, financial information, Garut District.

\begin{abstract}
Abstrak.Peranan informasi sangat penting dalam sektor pembiayaan pertanian. Tersedianya informasi yang jelas dan tepat dapat menentukan keberhasilan petani dalam memperoleh pembiayaan untuk usaha tani. Kegiatan pengabdian kepada masyarakat diselenggarakan dalam rangka peningkatan pengetahuan dan ketrampilan petani untuk mengakses informasi mengenai pembiayaan dari berbagai sumber-sumber pembiayaan. Kegiatan ini menerapkan metode penyuluhan, pelatihan dan pendampingan. Materi kegiatan pengabdian kepada masyarakat ini yaitu memberikan sosialisasi mengenai berbagai sumber-sumber pembiayaan di lingkungan sekitar petani, dan berbagai informasi terkait dengan syarat-syarat untuk mendapatkan pembiayaan dari berbagai sumber-sumber pembiayaan, serta aktivitasaktivitas apa saja yang perlu dilakukan dalam rangka mendapatkan akses informasi pembiayaan.
\end{abstract}

Kata Kunci: pengabdian kepada masyarakat, informasi pembiayaan, Kabupaten Garut 


\section{Pendahuluan}

Mayoritas usaha tani di Indonesia dilakukan oleh petani kecil yang pada umumnya merupakan usaha tani hulu dalam memproduksi bahan baku pertanian. Beberapa permasalahan masih dijumpai pada usaha tani yang dijalankan oleh petani kecil, salah satunya adalah keterbatasan modal untuk usaha tani. Secara umum, sumber pembiayaan untuk petani terbagi atas dua jenis yaitu formal dan informal (Nurmanaf, 2007). Sumber pembiayaan formal pada umumnya disediakan oleh bank, baik oleh bank pemerintah maupun swasta, lembaga keuangan mikro. Petani mengakses kredit untuk mendapatkan modal dalam usaha pertaniannya (Hartono dkk, 2013). Sedangkan sumber keuangan informal dapat berasal dari kios pupuk/pengecer resmi, pembeli, tengkulak (Nurmanaf, 2007).

Studi yang dilakukan oleh Wulandari dkk (2017) menjelaskan secara detail bahwa petani di Indonesia dapat mengakses pembiayaan melalui sumbersumber pembiayaan yang tersedia, yaitu bank, lembaga keuangan mikro (LKM), asosiasi petani, pembeli (pedagang), kios pupuk dan sumber lainnya seperti dari keluarga dan teman. Studi tersebut menjelaskan bahwa sumber-sumber tersebut mempunyai pembiayaan dalam bentuk yang berbeda, contohnya bank dan LKM menyediakan kredit, asosiasi petani dan pedagang menyediakan input-input pertanian, sedangkan kios pupuk menyediakan pembiayaan dalam bentuk fleksibilitas dalam melakukan pembayaran input-input pertanian yang dibeli oleh petani.

Kabupaten Garut merupakan salah satu daerah produksi sayuran di Jawa Barat. Sektor pertanian berperan penting dalam kehidupan sosial ekonomi masyarakat di Kabupaten Garut, dimana pertanian masih merupakan sumber lapangan kerja bagi penduduknya (Kabupaten Garut, 2014). Kentang merupakan salah satu komoditas hortikultura yang dikembangkan di Kabupaten Garut karena iklimnya yang sesuai untuk perkembangan dan pertumbuhan kentang.

Petani kentang di Kabupaten Garut pada umumnya hanya mempunyai akses permodalan yang bersumber dari pembiayaan informal. Hasil penelitian sebelumnya dari Wulandari dkk (2018) menunjukkan bahwa mayoritas petani tidak mempunyai akses ke sumber pembiayaan formal. Hal ini dapat disebabkan kurangnya pengetahuan petani dalam informasi yang terkait dengan pembiayaan dari berbagai sumber pembiayaan untuk usahatani petani, padahal informasi berperan sangat penting dalam pembiayaan usahatani. Informasi yang tersedia secara jelas dan tepat dapat menentukan kesuksesan dalam mendapatkan pembiayaan usahatani, seperti kejelasan sifat, syarat dan prosedur pembiayaan yang tersedia dapat memudahkan dalam pemilihan pembiayaan yang dituju. Hal ini dapat meningkatkan kesempatan dalam mendapatkan pembiayaan bagi petani.

Beberapa upaya perlu dilakukan terkait dengan penyebaran informasi pembiayaan, yaitu melalui kegiatan penyuluhan berbagai sumber informasi pembiayaan dan beberapa syarat penting dalam upaya memperoleh pembiayaan, dan juga kegiatan fasilitasi dan pendampingan akses terhadap informasi pembiayaan.

Program pengabdian kepada masyarakat yang dilakukan ini memiliki tujuan dalam peningkatan pengetahuan dan keterampilan petani untuk mengakses berbagai informasi pembiayaan dan beberapa syarat penting dalam upaya memperoleh pembiayaan usahatani. Kegiatan pelatihan dan pendampingan dalam mengakses berbagai informasi pembiayaan ini diharapkan dapat meningkatkan kesempatan dalam mendapatkan pembiayaan bagi petani.

\section{Metode}

Kegiatan Pengabdian Kepada Masyarakat (PPM) yang dilaksanakan oleh Universitas Padjadjaran ini diadakan di Kecamatan Pasirwangi Kabupaten Garut. 
Kegiatan PPM yang dilaksanakan ini memiliki rangkaian kegiatan yang melibatkan petani dan pengurus kelompok tani yang secara aktif terlibat di dalamnya. Kecamatan Pasirwangi dipilih sebagai tempat penyelenggaraan PPM UNPAD karena latar belakang wilayah ini sebagai salah satu sentra produsen tanaman hortikultura, dengan komoditas utama yang dibudidayakan adalah kentang.

Tahapan pelaksanaan pengabdian kepada masyarakat dimulai dengan penggalian informasi tentang potensi pertanian di wilayah Kecamatan Pasirwangi. Selanjutnya dilaksanakan kegiatan konsultasi dan koordinasi dengan pihak Dinas Pertanian Kabupaten Garut dan BPP/UPT Pertanian di wilayah Kecamatan Pasirwangi. Hasil koordinasi ini didapatkan kelompok tani sasaran yang sesuai dengan tema dan tujuan dari kegiatan PPM ini. Kelompok tani yang ditentukan dalam koordinasi ini adalah Kelompok Tani di Desa Sarimukti yang memiliki usaha utama pada budidaya kentang.

Kegiatan Pengabdian Kepada Masyarakat di Kelompok Tani di Desa Sarimukti telah dilaksanakan pada bulan April sampai dengan November 2019. Metode pelaksanaan kegiatan yang telah diaplikasikan adalah penyuluhan. Penyuluhan dilakukan kepada anggota dan pengurus kelompok tani, kemudian ditindaklanjuti dengan penelusuran informasi pembiayaan. Kedua kegiatan tersebut diteruskan dengan pendampingan, terutama dalam hal pencatatan analisa usahatani yang dilaksanakan. Kegiatan PPM Unpad ini dilaksanakan secara terintegrasi dengan kegiatan Kuliah Kerja Nyata Mahasiswa (KKNM) Unpad. Pendampingan oleh mahasiswa KKNM dan petugas pertanian setempat secara aktif membina petani dalam melaksanakan penelusuran akses informasi pembiayaan.

\section{Hasil dan Pembahasan}

Kegiatan PPM Universitas Padjadjaran ini dilaksanakan di Kabupaten Garut sebagai salah satu produsen utama komoditas hortikultura terutama sayuran di Provinsi Jawa Barat. Komoditas sayuran utama yang banyak dibudidayakan di wilayah Kabupaten Garut yaitu kentang. Komoditas kentang ini termasuk dalam komoditas unggulan sayuran baik di tingkat daerah maupun nasional. Produksi kentang di tingkat Kabupaten Garut yang tersaji dalam Tabel 1.

Komoditas kentang di wilayah Kabupaten Garut mayoritas dibudidayakan di beberapa kecamatan dengan sentra utama secara berurutan yaitu Pasirwangi, Cikajang, Cisurupan dan daerah lainnya (Dinas Pertanian Garut, 2018). Pada tabel 1 dapat dilihat bahwa sentra utama kentang di Kabupaten Garut yaitu Kecamatan Pasirwangi. Kecamatan Pasirwangi memiliki rata-rata produksi kentang mencapai 36.400 ton dalam kurun waktu tahun 2013-2017. Dalam kurun waktu tersebut, produksi kentang dari Kecamatan Pasirwangi juga mengalami peningkatan produksi pada setiap tahun produksinya. 
Tabel 1. Sentra Produksi Kentang di Beberapa Kecamatan, Kabupaten Garut, Tahun 2013-2017

\begin{tabular}{|c|l|r|r|r|l|l|r|r|}
\hline \multirow{2}{*}{ No } & \multirow{2}{*}{ Kecamatan } & \multicolumn{5}{|c|}{ Produksi Kentang (Ton) } & \multirow{2}{*}{ Jumlah } & \multirow{2}{*}{ Rata-Rata } \\
\cline { 3 - 8 } & & $\mathbf{2 0 1 3}$ & $\mathbf{2 0 1 4}$ & $\mathbf{2 0 1 5}$ & $\mathbf{2 0 1 6}$ & $\mathbf{2 0 1 7}$ & & \\
\hline 1 & Cikajang & 35.435 & 31.247 & 28.371 & 27.439 & 27.904 & 150.396 & 30.079 \\
\hline 2 & Cigedug & 20.184 & 20.556 & 16.346 & 17.104 & 16.694 & 90.884 & 18.177 \\
\hline 3 & Cisurupan & 21.092 & 18.211 & 27.931 & 29.594 & 27.214 & 124.042 & 24.808 \\
\hline 4 & Sukaresmi & 8.830 & 9.336 & 13.029 & 21.348 & 25.374 & 77.917 & 15.583 \\
\hline 5 & Pasirwangi & 25.886 & 19.245 & 39.533 & 45.807 & 51.529 & 182.000 & 36.400 \\
\hline 6 & $\begin{array}{l}\text { Kecamatan } \\
\text { lainnya }\end{array}$ & 46.820 & 40.754 & 36.933 & 37.076 & 34.047 & 195.630 & 39.126 \\
\hline
\end{tabular}

\section{Kegiatan PPM ini} diselenggarakan untuk meningkatkan pengetahuan dan keterampilan petani dalam mengakses berbagai informasi pembiayaan dan beberapa syarat yang penting dalam upaya memperoleh pembiayaan dari beberapa sumber pembiayaan. Kegiatan pelatihan dan pendampingan dalam mengakses berbagai informasi pembiayaan ini diharapkan dapat meningkatkan kesempatan dalam mendapatkan pembiayaan bagi petani.

Kegiatan pengabdian kepada masyarakat yang dilakukan terkait dengan penyebaran informasi pembiayaan, yaitu melalui kegiatan penyuluhan berbagai sumber informasi pembiayaan dan beberapa syarat yang penting untuk memperoleh pembiayaan dari sumber-sumber pembiayaan, dan juga kegiatan fasilitasi dan pendampingan akses terhadap informasi pembiayaan dan pencatatan usahatani.

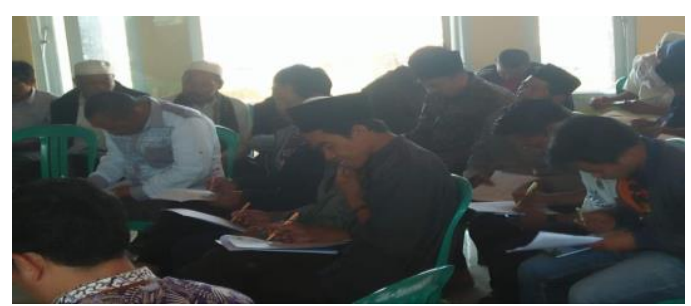

Gambar 1. Peserta PPM sedang membaca materi PPM

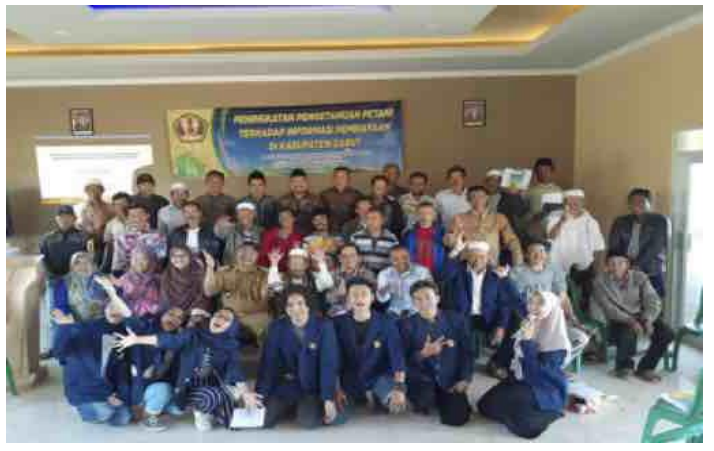

Gambar 2. Kegiatan PPM di Kecamatan Pasirwangi Kabupaten Garut

Materi pada kegiatan PPM ini meliputi sosialisasi mengenai berbagai sumber-sumber pembiayaan di lingkungan sekitar petani, dan berbagai informasi terkait dengan syarat-syarat untuk mendapatkan pembiayaan dari berbagai sumber-sumber pembiayaan, serta aktivitas-aktivitas apa saja yang perlu dilakukan dalam rangka mendapatkan akses informasi pembiayaan.

Penyebaran informasi khususnya mengenai informasi pembiayaan penting untuk dilakukan, seperti yang dijelaskan oleh Harsanto (2014) bahwa pada saat ini dunia saling terhubung dimana dengan adanya teknologi pada bidang komunikasi dan informasi yang maju berdampak pada alur komunikasi dan efek ekonomi secara cepat. Teknologi informasi dapat dimanfaatkan untuk mengembangkan suatu bisnis (Permana 
dan Cendana, 2019). Secara umum, sumber-sumber pembiayaan yang terdapat di lingkungan sekitar petani yaitu bank, lembaga keuangan mikro (LKM), pemerintah melalui kelompok petani, pembeli (pedagang), kios sarana produksi pertanian dan sumber pembiayaan lainnya seperti pembiayaan dari keluarga, tetangga dan teman.

Selanjutnya, peserta pelatihan diberikan sosialisasi mengenai produkproduk pembiayaan dari berbagai bank yang terdapat di sekitar peserta. Sosialisasi ini menjadi penting mengingat petani sebagai pelaku usaha pertanian memerlukan informasi mengenai produk perbankan yang dapat diakses sebagai sumber permodalan usaha petani. Ningrum (2012) menjelaskan bahwa berbagai produk perbankan belum termanfaatkan oleh pelaku usaha karena keberadaan lembaga pembiayaan belum terinformasikan secara luas sehingga banyak pelaku usaha yang hanya bergantung pada modal sendiri. Selanjutnya Ningrum (2012) juga menjelaskan bahwa akses terhadap dukungan modal dapat terlaksana bagi pelaku usaha dengan tersedianya informasi mengenai produk pembiayaan dari perbankan dan lembaga keuangan lainnya.

Sosialisasi produk-produk perbankan kepada peserta pelatihan dengan cara menjelaskan produk perbankan melalui brosur. Brosur merupakan bagian yang penting dari suatu strategi promosi dalam menyebarkan informasi terkait dengan usaha suatu lembaga (Susilowati, 2018). Lebih lanjut Susilowati (2018) menjelaskan bahwa penyebaran informasi misalnya dalam bentuk brosur merupakan suatu usaha untuk mengenalkan kepada masyarakat mengenai lembaga dan produknya.

Berdasarkan penelitian Lestari (2012), partisipasi dan keaktifan petani peserta dalam suatu pelatihan atau kegiatan dalam mengikuti tahapan program dapat menentukan tingkat keberhasilan program/kegiatan tersebut. Selanjutnya petani memiliki peran yang penting dalam kegiatan dengan tingkat kehadiran yang tinggi pada pelaksanaan program kegiatan (Lestari, 2012), berperan aktif dalam kegiatan diskusi (Muchtar dkk, 2015; Wulandari dkk, 2019). Selain itu, peran petani juga menentukan keberhasilan program dengan kemauan para petani peserta untuk mengimplementasikan semua tahapan program kegiatan dalam kehidupan mereka.

Dalam kegiatan pengabdian kepada masyarakat, petani peserta menjadi subjek utama dalam tahapan pelaksanaan kegiatannya. Petani peserta memiliki tingkat partisipasi yang tinggi dengan ditunjukkan dengan antusiasmenya yang tinggi, terutama dalam kegiatan diskusi dan tanya-jawab. Pada saat kegiatan ini, petani sangat aktif dalam membagikan pengalaman mereka perihal akses pembiayaan, sekaligus banyak menanyakan mengenai materi yang merupakan hal yang baru bagi petani di wilayah Kecamatan Pasirwangi.

Petani peserta juga menunjukkan antusiasme dalam tahapan pelaksanaan pelatihan dan pendampingan akses informasi pembiayaan. Meskipun mengalami kesulitan, petani sangat tertarik untuk mengisi buku pencatatan usahatani yang disediakan oleh panitia pengabdian kepada masyarakat.

Mekanisme kegiatan pengabdian kepada masyarakat ini dilaksanakan secara bersama-sama dengan melibatkan petugas pertanian setempat dan mahasiswa KKNM UNPAD. Mahasiswa berperan dalam mendampingi petani peserta dalam mengisi buku pencatatan usahatani sebagai bagian dari keberhasilan dalam mengakses pembiayaan. 


\section{Kesimpulan dan Saran}

\begin{tabular}{lcr}
\multicolumn{1}{c}{ Kegiatan } & \multicolumn{1}{c}{ PPM } & ini \\
diselenggarakan & dalam & upaya \\
peningkatan & pengetahuan & dan \\
ketrampilan khususnya petani & dalam \\
mengakses & informasi & mengenai \\
pembiayaan dari berbagai & sumber- \\
sumber pembiayaan.
\end{tabular}

Kegiatan PPM ini dilaksanakan di Kecamatan Pasirwangi, Kabupaten Garut. Metode pelaksanaan yang digunakan adalah penyuluhan, pelatihan dan pendampingan aktivitas untuk dapat mengakses informasi pembiayaan usahatani.

Partisipasi masyarakat dalam pelaksanaan program ini dinilai sangat baik. Petani aktif melakukan diskusi dalam pelaksanaan program ini dan antusiasme petani juga ditunjukkan dengan keinginan petani untuk didampingi dalam implementasi dari kegiatan ini. Teknis pelaksanaan pelatihan yaitu dengan memberikan pengetahuan akses informasi pembiayaan usahatani.

Pendampingan dan fasilitasi diperlukan untuk mengontrol proses aktivitas selanjutnya, sehingga keberlanjutan penerapan aktivitas untuk dapat mengakses informasi pembiayaan usahatani di tingkat petani dapat terus berlanjut dan berkembang.

\section{UCAPAN TERIMA KASIH}

Ucapan terima kasih yang mendalam kami sampaikan kepada para petani dan semua pihak yang telah mendukung pelaksanaan kegiatan PPM ini. Selanjutnya, kami sampaikan terima kasih kepada Universitas Padjadjaran melalui Direktorat Riset, Pengabdian kepada Masyarakat dan Inovasi untuk dukungan finansial dalam pelaksanaan kegiatan PPM ini.

\section{DAFTAR PUSTAKA}

Dinas Pertanian Kabupaten Garut. (2018). Data Base 2013-2017 Tanaman Hortikultura di Kabupaten Garut. Dinas Pertanian Pemerintah Kabupaten Garut (ID).

Harsanto, B. (2014). Aspek etik dan sistemik dalam ekonomi dan bisnis islam: mengambil pelajaran dari berulangnya krisis keuangan global. AlQalam, Vol. 31, No. 1, pp. 187212.

Hartono, R., Hadi, S., Juanda, B dan Rusastra, I. W. (2013). Penyusunan alternatif model kelembagaan kredit usaha pertanian di perdesaan. Informatika Pertanian, Vol. 22, No. 2, pp. 121-135.

Kabupaten Garut. (2014). Rencana Pembangunan Jangka Menengah Daerah Kabupaten Garut Tahun 2014-2019. Pemerintah Kabupaten Garut.

Lestari, D. (2012). Analisis partisipasi petani dalam kegiatan sekolah lapang pengelolaan tanaman terpadu (SLPTT) di Desa Gerung Utara Kecamatan Gerung Kabupaten Lombok Barat. Jurnal Pertanian Media Bina Ilmiah, Vol. 6, No. 3, pp. 70-77.

Muchtar, K., Susanto, D dan Purnaningsih, N. (2015). Adopsi teknologi petani pada sekolah lapangan pengelolaan tanaman terpadu (SL-PTT). Jurnal Penyuluhan, Vol. 11, No. 2, pp. 176185.

Ningrum, T. S. (2012). Penyelesaian kredit bermasalah dalam perjanjian kredit ekspor Bank Jateng di Semarang. Skripsi. Fakultas Hukum Universitas Diponegoro Semarang.

Nurmanaf, A. R. (2007). Lembaga informal pembiayaan mikro lebih dekat dengan petani. Analisis Kebijakan Pertanian, Vol. 5, No. 2, pp. 99-109. 
Permana, S. D. H dan Cendana, M. (2019). Pemanfaatan sosial media sebagai strategi promosi bagi sustainability bisnis UMKM. Ethos (Jurnal Penelitian dan Pengabdian Masyarakat), Vol. 7, No.2, pp. 163169.

Susilowati, L. (2018). Model strategi tumbuh dan bertahan pada pengelolaan Baitul Maal Wat Tamwil (BMT) di Kabupaten Tulungagung dan Ponorogo. Iqtishadia Jurnal Ekonomi dan Perbankan Syariah, Vol. 5, No. 2, pp. 163-187. E-ISSN: 2442-3076.

Wulandari E, Meuwissen M, Karmana MH and Oude Lansink A. (2017). Performance and access to finance in Indonesian horticulture. British Food Journal, Vol. 119, No. 3, pp. 625638.

Wulandari, E, Ernah dan Supyandi D. (2018). Akses terhadap Berbagai Sumber Pembiayaan dan Kaitannya terhadap Produktivitas Usaha Tani Hortikultura di Jawa Barat. Laporan penelitian. Fakultas Pertanian Universitas Padjadjaran.

Wulandari E, Supyandi D. dan Ernah (2019). Pelatihan pencatatan finansial usahatani di Kabupaten Garut. Ethos (Jurnal Penelitian dan Pengabdian Masyarakat), Vol. 7, No.1, pp. 120-126. 